DOI: https://doi.org/10.24127/ajpm.v8i1.1560

\title{
EFEKTIVITAS MODEL PEMBELAJARAN TIPE TEAM ASSISTED INDIVIDUALIZATION (TAI) DITINJAU DARI PRESTASI BELAJAR DAN SELF-EFFICACY MATEMATIKA SISWA SMP
}

\author{
Azwar Anwar ${ }^{1}$, Rusgianto Heri Santosa ${ }^{2}$ \\ ${ }^{1,2}$ Pendidikan Matematika, Universitas Negeri Yogyakarta \\ E-mail: $\quad$ azwar.anwar2016@student.uny.ac.id ${ }^{l)}$ \\ santosa_rh@yahoo.co.id ${ }^{2)}$
}

Received 2 October 2018, Received in revised form 10 November 2018; Accepted 24 December 2018

\begin{abstract}
This study aims: (1) to describe the effectiveness of Team Assisted Individualization (TAI) type of cooperative learning model and scientific approach in terms of learning achievement and self efficacy, (2) comparing the effectiveness of Team Assisted Individualization (TAI) type of cooperative learning model and scientific approach in terms of learning achievement and self efficacy. The type of research used is quasi experimental research. The population in this study were class VII students of SMP Negeri 2 Depok. Data were analyzed descriptively, hypothesis testing using one-sample t-test, MANOVA test with $T^{2}$ Hotteling formula. The results of the study are as follows. (1) The implementation of effective Team Assisted Individualization (TAI) type of cooperative learning model, while the scientific approach is not effective in terms of learning achievement and self efficacy. (2) The application of the Team Assisted Individualization (TAI) type of cooperative learning model is more effective than the application of the scientific approach.
\end{abstract}

Keywords:Learning Achievement; Self-Efficacy; Team Assisted Individualization (TAI).

\section{PENDAHULUAN}

Pendidikan merupakan salah satu upaya dalam meningkatkan perkembangan dan kualitas suatu bangsa. Dengan pendidikan juga dapat mengetahui proses dalam menjalani kehidupan. Tentunya dalam hal ini untuk mengetahui semua itu perlu adanya suatu proses yang dinamakan belajar. Dalam keseluruhan proses belajar itu merupakan hal yang pokok dalam dunia pendidikan terutama di sekolah. Dengan belajar maka akan terjadi perubahan pada individu melalui pengalaman, dan bukan karena pertumbuhan atau perkembangan tubuhnya atau karakteristik seseorang sejak lahir (Al-Tabany, 2014: 18). Dalam belajar siswa tentunya ingin mendapatkan hasil semaksimal mungkin karena dengan hasil belajar yang maksimal memudahkan mereka untuk melanjutkan studi dan menggapai cita-cita.

Matematika merupakan salah satu mata pelajaran wajib yang harus dipelajari siswa pada setiap jenjang pendidikan. Mengingat pentingnya pelajaran matematika ini, maka guru diharapkan mampu mendidik dan melatih siswanya agar dapat menguasai matematika. Tujuan diberikannya matematika ditingkat sekolah adalah untuk melatih siswa berpikir, bernalar secara kritis, dan logis dalam memecahkan masalah dan mampu mengkondisikan ide atau gagasan. Masih sering ditemui dalam pembelajaran matematika di sekolah yang terjadi selama ini adalah guru lebih cenderung aktif dibanding siswa atau dengan kata lain pembelajaran matematika di kelas masih berfokus kepada guru sebagai satu-satunya 
sumber pengetahuan (Hariyati, Mardiayana, \& Usodo 2013). Oleh karena berdampak pada hasil belajar yang diperoleh siswa belum memuaskan. Dalam pembelajaran matematika siswa kurang memahami masalah dan merencanakan penyelesaian masalah. Hal-hal yang mempengaruhi hasil belajar berdampak juga pada rendahnya nilai yang diperoleh siswa.

Rendahnya nilai yang diperoleh siswa bukan semata dipengaruhi oleh aspek kognitif, melainkan juga dipengaruhi oleh aspek afektif siswa terhadap kemampuan yang dimiliki. Aspek afektif juga mempengaruhi hasil belajar siswa. Retnowati (2016: 11) menjelaskan bahwa kegiatan belajar juga dipengaruhi oleh aspek afektif yang berkaitan dengan perasaan, seperti motivasi belajar yang rendah dan keyakinan diri yang kurang dalam pembelajaran matematika dapat menjadi sumber masalah kognitif siswa yaitu masalah dalam melibatkan diri secara aktif untuk memahami materi pembelajaran.

Salah satu aspek afektif menurut Malpass, O'neil, dan Hocevar (2010: 287) yaitu self-efficacy memiliki peranan penting dalam prestasi siswa. Beberapa penelitian menunjukkan bahwa self-efficacy siswa dalam pembelajaran matematika akan membantu memprediksi seberapa besar pengaruh self-efficacy siswa terhadap kemampuan siswa dalam menyelesaikan soal matematika. Faktor self-efficacy siswa yang masih belum maksimal dan perlu menjadi perhatian. Banyak siswa yang menganggap dirinya tidak yakin dengan kemampuannya dalam menyelesaikan soal, sehingga dalam pembelajaran mereka sulit untuk belajar dan mendapatkan informasi dengan baik. Oleh karena itu, self- efficacy siswa sangat penting dalam menyelesaikan soal-soal matematika.

Self-efficacy siswa merupakan salah satu penyebab keberhasilan dan kegagalan dalam belajar matematika. Lunenburg (2011: 1-2) menyatakan bahwa self-efficacy memiliki pengaruh yang kuat terhadap pembelajaran, karena dengan self-efficacy akan berusaha mencoba untuk belajar dan mengerjakan tugas yang mereka yakini akan dapat berhasil. Kemampuan pengetahuan dan self-efficacy siswa terhadap pembelajaran matematika harus dikembangkan oleh siswa pada saat mempelajari matematika.

Berdasarkan uraikan yang dijelaskan di atas bahwa kendala yang paling dominan yaitu pembelajaran cenderung berpusat pada guru dan konvensional, dalam pembelajaran matematika guru belum memanfaatkan strategi/ inovatif dan efektif dalam meningkatkan prestasi belajar siswa. Salah satu yang dapat dilakukan adalah melaksanakan pembelajaran kooperatif yaitu menyumbangkan ide bahwa siswa yang bekerja sama dalam belajar dan bertanggung jawab terhadap teman satu timnya mampu membuat diri mereka belajar sama baiknya (Slavin, 2005: 15). Dalam pembelajaran kooperatif adalah membelajarkan kepada siswa keterampilan berkerjasama dan kooperatif. Keterampilan berkerjasama tersebut sangat penting bagi siswa, karena pada dunia kerja sebagian besar dilakukan secara kelompok. Menurut Sugiyanto, (2010: 37) strategi pembelajaran kooperatif merupakan pembelajaran yang berfokus pada penggunaan kelompok kecil siswa untuk bekerja sama dalam memaksimalkan kondisi belajar untuk mencapai tujuan belajar. Salah satunya adalah berdasarkan penelitian dasar yang mendukung penggunaan pembelajaran kooperatif untuk 
meningkatkan pencapaian prestasi para siswa, dan juga akibat-akibat positif lainnya yang dapat mengembangkan hubungan antar kelompok, penerimaan terhadap teman sekelas yang lemah dalam bidang akademik, dan meningkatkan rasa percaya diri. Hal ini masih belum terlihat bahwa guru.

Dalam pembelajaran kooperatif, siswa akan mencapai tujuan apabila siswa yang lain juga mencapai tujuan tersebut, artinya tujuan akan dicapai apabila seluruh anggota kelompok ikut andil untuk mencapai tujuan. Ada beberapa macam model pembelajaran kooperatif learning yaitu Numbered Heads Together (NHT), Student Team Achievement Development (STAD), Teams Games Tournament (TGT), Jigsaw, Cooperatif Integerated Reading and Composition (CIRC), Team Assisted Individualization (TAI) dan lain-lain.

Salah satu model yang akan digunakan dalam penelitian ini adalah model pembelajaran kooperatif tipe Team Assisted Individualization (TAI). Dengan pembelajaran tipe TAI dapat membuat siswa dapat bekerja sama timtim kooperatif, mengemban tanggung jawab dan memeriksa secara rutin, serta saling membantu satu sama lain dalam menghadapi masalah (Kusnaeni \& Heri Retnawati, 2016). Model pembelajaran kooperatif tipe TAI belum banyak diterapkan di SMP. Oleh karena itu perlu adanya sebuah inovasi dalam memberikan pembelajaran di sekolah. Slavin (2005: 187) TAI dirancang untuk menyelesaikan masalah yang membuat metode pengajaran individual menjadi efektif. Dengan membuat para siswa bekerja dalam tim-tim pembelajaran kooperatif dan mengemban tanggung jawab mengelola secara rutin, saling membantu satu sama yang lain dalam menghadapi masalah, dan saling member dalam menghadapi masalah.
Struktur dalam TAI memungkinkan siswa untuk saling bekerja sama untuk mencapai tujuan bersama. Oleh sebab itu dalam menghadapi masalah tersebut siswa harus saling berkomunikasi dalam melaksanakan tugas mereka sehingga nantinya akan berdampak pada hasil dan prestasi belajarnya. Penelitian Martyanti (2016) menyatakan bahwa pendekatan pembelajaran (problem solving dengan setting kooperatif tipe TAI memiliki keunggulan yaitu adanya kegiatan individu dimana siswa terlibat langsung dalam penemuan konsep dan penyelesaian masalah secara individu dengan memanfaatkan pemahaman dan kemampuan prasyarat yang mereka miliki, apabila mengalami kesulitan maka siswa dapat mendiskusikan dengan anggota kelompok yang lainnya. Sedangkan dengan penelitian Setianingsih (2016: 25) menyatakan bahwa pendekatan pembelajaran problem solving setting TAI efektif karena dalam satu kelompok saling membantu untuk menyelesaikan masalah-masalah yang diberikan sehingga berimbas masalah lebih mudah untuk diselesaikan dan siswa dapat mempelajari konsep dengan lebih baik serta membuat siswa lebih bertanggung jawab dalam mencapai kesuksesan kelompoknya. Sementara menurut (Hariyati, Mardiayana, \& Usodo 2013), dengan pembelajaran TAI dapat meningkatkan kecerdasan logika matematika, kecerdasan linguistik, dan prestasi belajar matematika siswa.

Pada penelitian ini pembelajaran TAI juga diharapkan untuk mengembangkan self-efficacy siswa sehingga dengan kepercayaan diri dapat menyelesaikan masalah matematika. Jika pada penelitian sebelumnya hanya melakukan penelitian dengan melihat self confidence dan prestasi belajar siswa (Martyanti, 2016), kemampuan komunikasi dan pemecahan masalah 
(Kusnaeni \& Retnawati, 2013), berpikir kritis dan kedisiplinan belajar (Setianingsih, 2016). Dengan pembelajaran TAI diharapkan menjadi salah satu solusi yang dapat digunakan dalam pembelajaran matematika, misalnya keaktifan siswa dalam bekerja sama di tim, kegiatan individu siswa, dan bertanggung jawab atas hasil yang diperoleh.

Berdasarkan uraian di atas, tujuan penelitian ini untuk menguji keefektifan model pembelajaran kooperatif learning tipe Team Assisted Individualization (TAI) ditinjau dari prestasi belajar dan self-efficacy siswa dan perbandingan keefektifan TAI dengan pendekatan saintifik ditinjau dari prestasi belajar dan self-efficacy siswa

\section{METODE PENELITIAN}

Jenis penelitian yang digunakan adalah penelitian eksperimen semu (quasi experiment). Langkah-langkah yang dilakukan dalam penelitian ini yaitu : 1) mengambil secara acak dua kelompok dari kelompok belajar (kelas) yang ada; 2) memberikan pretest (tes awal) dan angket

pada kedua kelompok; 3) melakukan treatment dengan menerapkan pembelajaran Team AssitedIndividualizatin pada kelompok eksperimen sedangkan pada kelompok kontrol menerapkan pembelajaran pendekatan saintifik ; 4) memberikan posttest (tes akhir) dan angket pada kedua kelompok.

Rancangan eksperimen yang digunakan adalah pretest-posttest, Nonequivalent two Group Design. Secara skematis rancangan eksperimen yang digunakan dalam penelitian ini disajikan pada Tabel 1.

Tabel 1. Skema Rancangan Penelitian

\begin{tabular}{cccc}
\hline Kelompok & Tes awal & Perlakuan & Tes akhir \\
\hline $\mathrm{E}$ & $\mathrm{Y}_{1}$ & $\mathrm{X}_{1}$ & $\mathrm{Y}_{2}$ \\
$\mathrm{~K}$ & $\mathrm{Y}_{1}$ & $\mathrm{X}_{2}$ & $\mathrm{Y}_{2}$ \\
\hline
\end{tabular}

Keterangan :

E: Kelas eksperimen menggunakan Team Assited-Individualizatin

$\mathrm{K}$ : Kelas kontrol menggunakan pembelajaran pendekatan saintifik.

$\mathrm{Y}_{1}$ : Tes awal prestasi belajar dan angket self efficacy sebelum diterapkan pembelajaran

$\mathrm{Y}_{2}$ : Tes akhir prestasi belajar dan angket self efficacy setelah diterapkan pembelajaran

$\mathrm{X}_{1}$ : Perlakuan dengan Team AssitedIndividualizatin dengan pendekatan saintifik

$\mathrm{X}_{2}$ : Perlakuan dengan pembelajaran pendekatan saintifik
Dalam penelitian ini kelas eksperimen yang digunakan dikombinasi-kan dengan pendekatan saintifik.

Populasi dalam penelitian ini adalah seluruh siswa kelas VII SMP N 2 Depok Tahun Ajaran 2017/2018. Sampel penelitian ini adalah dipilih secara acak dan diperoleh 1 kelas ekperimen dan 1 kelas kontrol.

Instrumen tes yang digunakan yaitu tes kemampuan prestasi belajar siswa untuk mengukur prestasi belajar dan angket digunakan untuk mengukur 
self-efficacy siswa baik sebelum maupun sesudah perlakuan diberikan.

Analisis data yang digunakan adalah data kondisi awal dan akhir pada aspek prestasi belajar dan self-efficacy siswa dalam pembelajaran matematika dan juga dilihat dari statistik deskriptif. Pengujian tahap awal adalah uji one sample t-test yang bertujuan untuk melihat keefektifan model Team Assited-Individualizatin ditinjau dari self-efficacy dan prestasi belajar siswa terhadap matematika. Selanjutnya adalah melakukan uji multivariat (MANOVA) untuk melihat adanya perbedaan keefektifan terhadap kedua kelompok, apakah terdapat perbedaan secara signifikan antara Team AssitedIndividualizatin dan pembelajaran pendekatan saintifik ditinjau dari prestasi belajar dan self-efficacy.

\section{HASIL PENELITIAN DAN PEMBAHASAN}

Berdasarkan hasil penelitian pada Tabel 2, persentase ketuntasan belajar matematika untuk kelas model pembelajaran kooperatif tipe TAI sebelum perlakuan (pretest) yaitu 3,13\% (1 siswa yang mencapai KKM) dan sesudah perlakuan (posttest) yaitu $78,12 \%$ (25 siswa yang mencapai KKM) atau mengalami peningkatan sebesar $74,99 \%$. Sementara pada kelas kontrol diperoleh persentase ketuntasan sebelum perlakuan (pretest) prestasi belajar matematika yaitu $3,13 \%$ (1 siswa yang mencapai KKM) dan sesudah perlakuan (posttest) yaitu $43,75 \% \quad$ (14 siswa yang mencapai $\mathrm{KKM}$ ) atau mengalami peningkatan sebesar 40,62\%. Pada hasil tersebut menunjukkan bahwa kelas model pembelajaran kooperatif learning tipe TAI lebih efektif dalam meningkatkan prestasi belajar matematika siswa daripada kelas kontrol dengan pendekatan saintifik. Untuk model pembelajaran kooperatif yang digunakan dapat dikatakan efektif ditinjau dari prestasi belajar matematika jika skor rata-rata keseluruhan siswa minimal 70 (disesuaikan dengan KKM sekolah). Data tes prestasi belajar matematika siswa pada pretest maupun posttest untuk kedua kelas dapat dilihat pada Tabel 2.

Tabel 2. Data Prestasi Belajar Matematika Siswa Pretest dan Posttest

\begin{tabular}{lcccc}
\hline \multirow{2}{*}{ Deskripsi } & \multicolumn{2}{c}{ Kelas TAI } & \multicolumn{2}{c}{ Kelas Kontrol } \\
\cline { 2 - 5 } & Pretest & Posttest & Pretest & Posttest \\
\hline Rata-rata & 38,13 & 75,47 & 40,78 & 66,25 \\
Varians & 147,98 & 84,45 & 159,85 & 69,35 \\
Standar Deviasi & 12,16 & 9,19 & 12,64 & 8,33 \\
Persentasi Tuntas & $3,13 \%$ & $78,12 \%$ & $3,13 \%$ & $43,75 \%$ \\
\hline
\end{tabular}

Tabel 3. Data Self Efficacy Siswa Pretest dan Posttest

\begin{tabular}{lcccc}
\hline \multirow{2}{*}{ Deskripsi } & \multicolumn{2}{c}{ Kelas TAI } & \multicolumn{2}{c}{ Kelas Kontrol } \\
\cline { 2 - 5 } & Pretest & Posttest & Pretest & Posttest \\
\hline Rata-rata & 53,19 & 72,00 & 49,69 & 66,03 \\
Varians & 77,64 & 32,45 & 43,19 & 90,29 \\
Standar Deviasi & 8,81 & 5,70 & 6,57 & 9,50 \\
\hline
\end{tabular}


DOI: https://doi.org/10.24127/ajpm.v8i1.1560

Tabel 4. Hasil Uji One Sample t Test Kelas TAI dan Kelas Kontrol

\begin{tabular}{ccccc}
\hline \multirow{2}{*}{ Deskripsi } & \multicolumn{2}{c}{ Kelas TAI } & \multicolumn{2}{c}{ Kelas Kontrol } \\
\cline { 2 - 5 } & Sig. & Ket. & Sig. & Ket. \\
\hline Prestasi Belajar & 0,060 & Efektif & 0,000 & Tidak Efektif \\
Self Efficacy & 0,053 & Efektif & 0,000 & Tidak Efektif \\
\hline
\end{tabular}

Data hasil angket self efficacy matematika siswa pada pretest maupun posttest untuk kelas eksperimen dan kelas kontrol dapat dilihat pada Tabel 3. Untuk model pembelajaran kooperatif tipe TAI rata-ratanya adalah 53,19 sedangkan untuk kelas kontrol rataratanya adalah 49,69. Sedangkan setelah diberi perlakuan posttest nilai rata-rata self efficacy siswa pada kedua kelas mengalami peningkatan. Nilai rata-rata posttest self efficacy untuk kelas model pembelajaran kooperatif tipe TAI sebesar 72,00 atau mengalami peningkatan sebesar 18,81 dari pretest. Sedangkan nilai rata-rata posttest self efficacy untuk kelas kontrol sebesar 66,03 atau mengalami peningkatan sebesar 16,34 dari pretest.

Dari hasil tersebut menunjukkan bahwa terjadi peningkatan tertinggi pada model model pembelajaran kooperatif tipe TAI,sehingga dapat dikatakan bahwa model pembelajaran kooperatif tipe TAI lebih efektif dalam meningkatkan self efficacy daripada kelas kontrol.

Uji hipotesis digunakan untuk menguji keefektifan model pembelajaran. Untuk melihat keefektifan model pembelajaran kooperatif learning tipe TAI ditinjau dari prestasi belajar dan self efficacy siswa maka akan dilakukan uji one sample t test dapat dilihat pada Tabel 4.

Berdasarkan Tabel 5, diperoleh nilai signifikansi Hotelling's Trace yaitu $0,000>\alpha=0,05$ maka Ho ditolak,
Untuk nilai signifikansi untuk prestasi belajar dan self efficacy siswa secara keseluruhan $>\alpha=0,05$ sehingga Ho ditolak, dengan demikian dapat disimpulkan bahwa model pembelajaran kooepratif tipe TAI efektif ditinjau dari prestasi belajar dan self efficacy.

Sedangkan nilai signifikansi untuk prestasi belajar dan self efficacy siswa secara keseluruhan $<\alpha=0,05$ sehingga Ho diterima, dengan demikian dapat disimpulkan bahwa metode pembelajaran pendekatan saintifik tidak efektif ditinjau prestasi belajar dan self efficacy.

Untuk melakukan uji perbedaan keefektifan model dan metode pembelajaran ditinjau dari presatsi belajar dan self efficacy siswa aka dilakukan dengan menggunakan uji two group manova. Hasil uji two group manova dapat dilihat pada Tabel 5.

Tabel 5. Hasil Uji Perbedaan

Keefektifan Model

Pembelajaran Kooperatif Learning Tipe TAI dan Kelas Kontrol

\begin{tabular}{cccc}
\hline Effect & Value & F & Sig \\
\hline Hotelling's & 0,078 & $2,379^{\mathrm{b}}$ & 0,000 \\
\hline
\end{tabular}

dengan demikian skor rata-rata posttest prestasi belajar dan self efficacy matematika siswa pada kelas dengan model TAI serta kelas kontrol berbeda secara signifikan. Sehingga dapat 
disimpulkan bahwa terdapat perbedaan data posttest prestasi belajar, self efficacy siswa baik pada kelas eksperimen maupun kelas kontrol.

Menurut Hadinata, Syahruddin, dan Tegeh (2013) menyatakan bahwa model pembelajaran Team Assisted Individualization (TAI) dapat meningkatkan prestasi belajar matematika siswa karena pembelajaran ini mempunyai beberapa kelebihan, yaitu (1) Siswa yang kurang mampu dapat terbantu dalam menyelesaikan masalahnya, (2) siswa yang pandai dapat mengembangkan kemampuan dan ketrampilannya, (3) adanya tanggung jawab dalam kelompok dalam menyelesaikan permasalahannya, (4) siswa diajarkan bagaimana bekerjasama dalam suatu kelompok. Sedangkan Hariyati, Mardana, dan Usodo (2013) menyatakan bahwa model pembelajaran kooperatif tipe Team Assisted Individualization (TAI), siswa yang mempunyai semangat belajar yang tinggi dan memanfaatkan kemampuan bahasanya untuk mencerna soal-soal yang ada pada LKS dan juga dapat berkomunikasi dengan baik dengan teman-temannya dalam satu kelompok. Hal ini terlihat juga dari pembelajaran di kelas di mana siswa terlihat mempunyai kemauan yang tinggi dalam pembelajaran kelompok karena melibatkan pemikiran dari siswa yang lain sehingga dapat menyelesaikan suatu masalah matematika.

Ramlan (2013) bahwa model pembelajaran kooperatif tipe Team Assisted Individualization (TAI) dapat meningkatkan hasil belajar matematika, khususnya pada pokok bahasan aritmetika sosial yang sekaligus dapat meningkatkan self-efficacy siswa. Oleh sebab itu, perlu diperhatikan selfefficacy siswa dalam mengajar di kelas sehingga siswa mampu atas keyakinan yang dimilikinya. $\begin{array}{lrr}\text { Berdasarkan } & \text { skor } & \text { self-efficacy } \\ \text { menunjukkan } & \text { bahwa } & \text { terjadi } \\ \text { peningkatan pada hasil posttest. Hal ini } \\ \text { mengindikasikan } & \text { keyakinan } & \text { siswa }\end{array}$ dalam mengerjakan soal-soal yang telah diberikan dan yakin bahwa mereka memiliki keterampilan untuk melakukan sesuatu. Namun masih ada siswa yang mempunyai self-efficacy yang rendah, mungkin disebabkan karena ketidakpercayaan atas apa yang dikerjakan sehingga menjadikannya mudah menyerah, sehingga kesulitan dalam menyelesaikan masalah. Berbeda dengan siswa self-efficacy yang tinggi, mereka lebih mudah dalam mengerjakan soal dengan baik. Pembelajaran dengan model Team Assisted Individualization (TAI) menunjukkan lebih efektif dibandingkan dengan kelas kontrol yang menggunakan pendekatan saintifik. Keefektifan siswa dalam pembelajaran kooperatif TAI ditunjukkan dengan keaktifan antar siswa dalam tim saling berdiskusi dan berargumen, siswa berani bertanggung jawab atas hasil tim yang diperoleh dan kegiatan individu dari siswa berjalan dengan baik terutama dalam kehidupan sehari-hari. Hal ini sejalan dengan (Kusnaeni dan Retnawati, 2013) bahwa keefektifan pembelajaran dengan TAI disebabkan pada beberapa hal, diantaranya: (1) siswa berpartisipasi aktif dalam pembelajaran (2) siswa memiliki kesempatan lebih banyak dalam memanfaatkan pengetahuan dan keterampilan matematika (3) siswa dengan kemampuan matematika rendah dapat merespon permasalahan dengan cara mereka sendiri, dan (4) siswa terbiasa menghadapi permasalahan matematika dalam kehidupan seharihari.

Dari penjelasan di atas bahwa implikasi dari pembelajaran TAI dapat mengembangkan kemampuan siswa 
baik secara individu maupun secara kelompok. Selain itu, pembelajaran kooperatif perlu dipadukan dengan pendekatan/model pembelajaran lain untuk meningkatkan kemampuan atau kompetensi siswa.

\section{KESIMPULAN DAN SARAN}

Berdasarkan hasil penelitian dan pembahasan diperoleh kesimpulan sebagai berikut: (1) Pembelajaran kooperatif tipe Team Assisted Individualization (TAI) efektif ditinjau dari prestasi belajar dan self efficacy siswa, (2) Pembelajaran kooperatif tipe Team Assisted Individualization (TAI) lebih efektif daripada pembelajaran dengan pendekatan saintifik ditinjau dari prestasi belajar dan self efficacy siswa. Hal ini terlihat dari rata-rata skor TAI lebik baik daripada skor pendekatan saintifik dan juga berdasarkan analisis Manova.

Saran dari penelitian ini yaitu dalam menerapkan pembelajaran model kooperatif tipe TAI perlu diperhatikan kendala-kendala yang terjadi misalnya efisiensi waktu dalam belajar, kekompakan siswa dalam tim, dan memotivasi siswa dalam tampil maupun menyampaikan argumen. Selain itu perlu juga untuk mengkombinasikan model pembelajaran kooperatif yaitu tipe Team Assisted Individualization (TAI) dengan model atau pendekatan yang lain sehingga dapat menambah referensi pembelajaran ke depan yang lebih baik. Bagi peneliti lain yang tertarik untuk melakukan penelitian tentang model pembelajaran kooperatif tipe Team Assisted Individualization (TAI) perlu disesuaikan dengan masalah yang ada di sekolah atau di kelas serta juga harus mengetahui dari karakteristik sekolah dan kelasnya. Selain itu variabel yang diambil juga berhubungan dengan aspek kognitif dan aspek afektif yang akan diteliti serta penentuan materi matematika.

\section{DAFTAR PUSTAKA}

Al-Tabany, T. I. B. (2014). Mendesain Model Pembelajaran Inovatif, Progresif dan Kontekstual. Jakarta: Prenadamedia Group.

Hadinata, M. S., Syahruddin., \& Tegeh M. (2013). Pengaruh model pembelajaran Team Assisted Individualization (TAI) terhadap prestasi belajar IPS Kelas IV SD Gugus 4 Bondalem Kecamatan Tejakula. Jurnal Mimbar PGSD UNDIKSHA 1(1).

Hariyati, E, Mardiayana, \& Usodo. (2013). Efektivitas model pembelajaran kooperatif tipe Team Assisted Individualization (TAI) dan Problem Based Learning (PBL) pada prestasi belajar matematika ditinjau dari Multiple Intelligences siswa SMP Kabupaten Lampung Timur tahun pelajaran 2012/2013. Jurnal Elektronik Pembelajaran Matematika, 1(7), 721-731.

Kusnaeni \& Retnawati, H. (2013). Problem Posing dalam Setting Kooperatif Tipe TAI Ditinjau dari Kemampuan Komunikasi dan Pemecahan Masalah. Pythagoras: Jurnal Pendidikan Matematika, 8(1), 33-43.

Lunenburg, F. C. (2011). Self efficacy in the workplace: implication for motivation and performance. International Journal of Managements, Bussisnes, and Administration, 14(1), 1-6.

Malpass, J., O'neil, H. F., \& Hocevar, D. (2010). Self-regulation, goal orientation, self-efficacy, worry, and high-stakes math achievement for mathematically gifted high 
DOI: https://doi.org/10.24127/ajpm.v8i1.1560

school students. Roper Review, 21(4), 281-288.

Martyanti, A. (2016). Keefektifan pendekatan problem solving dengan setting STAD dan TAI ditinjau dari prestasi dan selfconfidence. Jurnal Riset Pendidikan Matematika, 3(1), 115.

Ramlan, M. (2013). Meningkatkan selfefficacy pada pembelajaran matematika melalui model kooperatif tipe Team Assisted Individualization (TAI) pada siswa kelas VIIA SMP Negeri 27 Makassar. Jurnal Matematika dan Pembelajaran (MAPAN), 1(1), 100-112.

Retnowati, E. (2016). Kajian masalah pembelajaran matematika di Sekolah Menengah Kejuruan dan alternatif solusinya. Artikel dipublikasikan dalam Pelatihan Pembelajaran Matematika Berbasis GeoGebra, Jurusan Pendidikan Matematika, Universitas Negeri Yogyakarta.

Setianingsih, H. (2016). Keefektifan problem solving dan guided inquiry dalam setting TAI ditinjau dari prestasi belajar, kemampuan berpikir kritis, dan kedisiplinan diri. Jurnal Riset Pendidikan Matematika, 3(2), 221-233.

Slavin, R. E. (2005). Cooperative learning: Teori, riset dan praktik. Bandung: Nusa Media.

Sugiyanto. (2010). Model-model pembelajaran inovatif. Surakarta: Yuma Pustaka. 